\title{
SYSTEM SIGNS OF A KAPELLMEISTER'S ACTIVITY
}

\section{Loshkov Yu. I.}

\section{INTRODUCTION}

The conductor's performance as a kind of professional music activity is a peculiar form of the "artificial" cultural tradition reproduction. Through the ages, the conductor's performance has been a part of a kapellmeister's activity, the peculiarity of which is stipulated by the evolutionary processes in the sphere of professional music. The attempts to define the term as "control over the process of collective orchestral performance" has been made since the XIXth century. Hugo Riemann formulated a term for "a kapellmeister" as («a vocal chapel conductor or an orchestra conductor») and for "a conductor" as («the one leading an orchestra, a choir, or an opera show»). At the same time, the German musicologist added to the conductor some creative characteristics of an interpreter, "the one who interprets the concept of the piece of music and unites the members of the band by this idea for joint implementation whilst performing» ${ }^{1}$. Hugo Riemann was specific about the term for the conductor as a performing musician and creative personality, nevertheless, the term for the kapellmeister was not duly explained and even, to some extent pointed at the identity of the abovementioned terms. In the Brockhaus and Efron Encyclopedic Dictionary, M. Soloviov the Russian composer and the education specialist defined the term for the kapellmeister referring to a person being at the head of a chapel, conducting it during the performance and having the rehearsals, and who was also formerly composing ${ }^{2}$. In such a way, it is possible to trace the widening of the scope of the kapellmeister's activity and determine the process of professional differentiation.

Further attempt to define the term for the kapellmeister as a kind of professional activity was also marked by vagueness. I. Yampolskyi considered the concept of "kapellmeister" - a choir conductor or an

\footnotetext{
1 Энгель Ю. Краткий музыкальный словарь. Москва, 1907. С. 61, 80.

2 Н. С. Капельмейстер // Ф. Брокгауз, И. Ефрон. Энциклопедический словарь. Т. ХІV. СПб., 1895. С. 146.
} 
instrumental chapel master, - as a synthesis of two German words: Kapelle - a choir, an orchestra and Meister - a master, a head ${ }^{3}$. M. Bahrynovskyi, interpreting the term for Meister as a master, maestro, an artist, a teacher, provided a well-considered definition of a term for Kapelmeister - a teacher at chapel ${ }^{4}$.

For the most part, contemporary researchers have not studied the problems of improving the conceptual framework. L. Sydelnykov did not differentiate between the term for "kapellmeister" and "conductor" and functionally identified them ${ }^{5}$. H. Makarenko confined himself to the definition of the term for kapellmeister taken from Soviet Music Encyclopedia $^{6}$. The problem of differentiation between the kapellmeister's and conductor's activity is considered in the thesis written by V. Pluzhnykov, who differentiating between these categories, functionally traced their antinomy within the limits of musical science, which does not give an opportunity of impartial characteristics and precise definition of kapellmeister's activity as a sociocultural phenomenon ${ }^{7}$. In this context, the goal of the research is to clear up the system features of kapellmeister's activity, which have been showing up in the course of the evolution of professional music. The stated objective resulted in the following scientific and research tasks:

- to determine the specificity of the development of the kapellmeister's activity,

- to characterize the system features of the kapellmeister's activity as a part of professional music activity,

- to distinguish the factors leading to the formation of the kapellmeister's activity as a system.

The methodological comprehension of the kapellmeister's activity as a system component of professional music activity was carried out by employing the system and activity approach, described in the papers of

${ }^{3}$ Музыкальная энциклопедия. Т. 2. Москва, 1974. С. 707.

${ }^{4}$ Багриновский М. Дирижерская техника рук (практическое руководство к изучению основ мануальной техники дирижирования). Москва, 1947. С. 7.

${ }^{5}$ Сидельников Л. Симфоническое исполнительство. Исторический очерк. Москва, 1991. С. 120-138.

6 Макаренко Г. Творчість диригента: Естетико-мистецтвознавчі виміри. Київ, 2005. С. 68.

7 Плужников В. Профессия дирижера и пути ее формирования в западноевропейской театрально-концертной практике XIX века : дисс. ... канд. искусствоведения : 17.00.03. Х., 2006. 237 с. 
H. Shchedrovytskyi ${ }^{8}$. Extrapolating his analytical presentations related to professional sphere of activity of a person as a process to music activity, "the professional music" appeared as a kind of artwork on the grounds of application of a peculiar "system of norms representing cultural tradition $»{ }^{9}$. In this context, the norms are both the elements of statistics and dynamics («the objective composition and activity structure»), which were differentiated by H. Shchedrovytskyi between "natural" and "artificial»" 10 . The main factor affecting the specificity of application of "natural" norms of professional activity is the living condition of a person in the environment; "artificial" norms include specific ways, means, forms and relations, being created and implemented through educational system and organization of music performance ${ }^{11}$. Thus, the logic of presenting the material under study is based on gradual clarification of specific features of the kapellmeister's activity as a system component of professional music activity.

\section{The kapellmeister's activity and professional music art}

An important role in the process of formation and functioning of normative system plays music creative practice, which "gives the pitch, rhythmic formulae, harmonic passages, types of structures certain, sometimes specific, more often generalized meanings, which are assigned to them in social music consciousness and live special life» ${ }^{12}$. In other words, it is within the context of performance evolution analysis that there is uncovered the fundamental of differentiation between folklore and professional sphere of music - the application of various types of reproduction of the cultural history: in the first one - mainly "natural", in the second one - mainly "artificial»" ${ }^{13}$. The peculiarity of this differentiation causes system distribution of music generally into two components: folklore and professional music. Therefore, H. Holovynskyi

\footnotetext{
${ }^{8}$ Щедровицкий Георгий Петрович. Избранные труды. Москва, 1995.

9 Лошков Ю. Профессиональное музыкальное искусство европейского типа // Мистецтвознавство ХХ століття. Херсон, 2017. С. 38-39.

${ }^{10}$ Щедровицкий Георгий Петрович. Избранные труды. Москва, 1995. С. 51.

11 Лошков Ю. Профессиональное музыкальное искусство европейского типа // Мистецтвознавство ХХ століття. Херсон, 2017. С. 38-39.

12 Назайкинский Е. О психологии музыкального восприятия. Москва, 1972. C. 17 .

13 Лошков Ю. Профессиональное музыкальное искусство европейского типа // Мистецтвознавство ХХ століття. Херсон, 2017. С. 38-39.
} 
the Russian musicologist, defining professional music and folklore as two systems of artistic thinking, firstly, traced the aesthetic foundation for differentiation («satisfaction of certain spiritual needs of society", "life purpose»), secondly, pointed at difference of structural elements («language semantics of professional European music", "means of expressiveness" etc. $)^{14}$

The fundamental components of "the system representing the norms of cultural tradition" of the professional music are as follows: music text as an object of representation, musical instruments as the means of text reproduction, technique and means of expressiveness as a way of text reproduction, music theory as a form of texts creation, systematization, preservation and transmission, the aesthetics of performance, based on interrelation between "a performing musician and an audience" (place of performance, behaviour onstage, appearance etc. $)^{15}$. Clarification of the peculiar features of normative system functioning allows uncovering, on the one hand, the specific character of the kapellmeister's activity; on the other hand, the signs of kapellmeister's activity as a part of professional music.

The position of a kapellmeister appeared in the XIth century at the court of the King of France. It was held by the most influential clergyman at court, called the master of the Chapel Royal ${ }^{16}$. In particular, the chapel choirmasters of Notre-Dame de Paris Léonin and Pérotin (the second half of the XIIth century - the beginning of the XIIIth century) were the masters, in other words, held specific hierarchical positions ${ }^{17}$. Alongside with this, the term for "chapel" in about VIIIth century meant the place for church service and clergymen serving at court, including choirmen $^{18}$.

Thus, the origin of the kapellmeister's activity is related to Medieval church culture, where music was a part of divine service. The kapellmeister's activity was forming when professional music performance had already branched out on the system level from traditional one based on "artificial" type of cultural tradition

14 Головинский Г. Композитор и фольклор: Из опыта мастеров XIX XX веков. Очерки. Москва, 1981. С. 50.

15 Лошков Ю. Профессиональное музыкальное искусство европейского типа // Мистецтвознавство ХХ століття. Херсон, 2017. С. 16.

${ }^{16}$ Музыкальная энциклопедия. Т. 2. Москва, 1974. С. 707.

${ }^{17}$ Грубер Р. Всеобщая история музыки. Москва, 1965. С. 216-217.

${ }^{18}$ Музыкальная энциклопедия. Т. 2. Москва, 1974. С. 706. 
reproduction. It touches upon both universal cultural situation (norm creating in the church while struggling against heresy), and specifically musical one (the formation of the professional liturgical chant since the IVth century.). That is, if solo and joint performance has revolutionized from folklore forms of music-making with an inherent "natural" type of the cultural tradition reproduction, then the kapellmeister's activity, one of the functions of which was control over the process of collective representation of a music text, originates exclusively from professional music activity based on creation and practical application of particular norms for this activity.

For a long time, the duties of music chapel master were combined with the duties of a minister ${ }^{19}$. The syncretic character of the devotional art caused multifunctional peculiarity of the chapel master's activity, whose fundamental monastic education enabled settling different issues, related to service. The focus on the quality of the music background of divine service caused gradual narrowing and specification of the kapellmeister's duties, however, the availability of order remained one of the main criteria for obtaining such a rank. The representatives of the Netherlands Polyphonic School (the XVth century) Johannes Ockeghem and Orlande de Lassus worked their way of professional becoming up from choristers to music directors of the leading chapels; the career of Guillaume Du Fay, whose music was recognized as "the greatest beauty of the time", from a chorister of Sistine Chapel in Rome to the music director in Cambrai, was facilitated by the activity in the sphere of theology, where the musician took a Bachelor's Degree in Paris ${ }^{20}$. The chapel master of St Mark's Basilica in Venice Gioseffo Zarlino the famous music theorist apart from music was actively engaged in theology. Francesco Cavalli and Pietro Marc'Antonio Cesti the founders of Venetian Opera School were actively cooperating with ecclesiastical chapels in Venice and Rome ${ }^{21}$. Besides, at the beginning of the XVIIIth century in Hanover, the music chapel was headed by a bishop A.Stefano, who in 1710 entrusted the kapellmeister's position to George Frideric

19 Глинский М. Очерки по истории дирижерского искусства // Музыкальный современник. 1916. № 3. С. 31.

${ }^{20}$ Грубер Р. Всеобщая история музыки. Москва, 1965. С. 287.

21 Ливанова Т. История западноевропейской музыки до 1789 г. Т. 1 : От античности к XVIII веку. Москва, 1986. С. 230-234. 
Handel $^{22}$. Thus, fruitful professional activity in combination with religious devotion gave the opportunity of career development to the highest position - the music chapel master - and public recognition.

Following the church tradition within the context of temporal court chapel's activity became the characteristic feature of aristocratic culture. Showing the diversity of sociocultural life in comparison with the life of the church affected the specific character of chapels' functioning as music organizations, which could consist of some bands of the specified purpose. Music of King Louis XIV consisted of three subsections: "Large Stable", which united the bandsmen of hunting music and wind music and was meant for the events taking place in the open air; "Chamber" included solo-instrumentalists, big orchestra "The King's 24 Violin-Family Instruments" and a small string orchestra, performing at dinner time, at the parties, balls etc.; "Chapel" was only vocal and was meant for the performance of wind music ${ }^{23}$. In Eisenstadt (the middle of the XVIIIth century) a chapel consisted of string and wind orchestras and a vocal group $^{24}$.

The increase in functional duties of chapels and gradual complication of the musical language caused professional differentiation under which the decisive criterion for the appointment to the position of the court chapel master became the quality of professional music activity, the recognition of which by the chapel owner determined the level of the kapellmeister's material support. In particular, Jean-Baptiste Lully, thanks to his activity at the head of court chapel of Luis XIV, was be stinking rich and accepted a title of nobility ${ }^{25}$. In 1740 Charles VI the emperor conferred a title of nobility to Georg Reiter a kapellmeister in the chapel of St. Stephen's Cathedral (Vienna). Franz Joseph Haydn, whose kapellmeister's activity was related to the family of princes Esterházy, in his correspondence, expressed his indignation at the fact that Wolfgang Amadeus Mozart had not been engaged in any emperor or

22 Ливанова Т. История западноевропейской музыки до 1789 г. Т. 2: XVIII век. Москва, 1982. С. 94.

23 Ромен Роллан. Музыкально-историческое наследие. Вып. 3: Музыканты прошлых дней. Музыкальное путешествие в страну прошлого. Москва, 1988. C. 106 .

24 Новак Л. Йозеф Гайдн. Жизнь, творчество, историческое значение. Москва, 1973. С. 157.

25 Материалы и документы по истории музыки. Т. II: XVIII век (Италия, Франция, Германия, Англия). Москва, 1934. С. 253. 
royal court ${ }^{26}$. In other words, the professional activity at the head of ecclesiastical or temporal music chapel for a long time had been the most prestigious among artistic occupations, which was stipulated not only by the feasibility of full uncover of creative potential but also by securing individual wealth.

Almost until the XVIIIth century, the kapellmeisters' professional activity had a decisive effect on the formation of the music culture of the developed European countries, which was related to the specific character of chapels' functioning. Just based on the analysis of kapellmeisters' professional activity Romain Rolland drew an inference of predominant influence of Italian music in the German music culture of the XVIIth century. ${ }^{27}$ It was related to the fact that, unlike solo and ensemble music-making of that time, the performance of music chapel was stable and social-oriented, while being limited to selected circles. Such situation promoted constant presentation of the pieces of music performed by chapel masters or the authors honoured/respected by them.

Prestige value of the kapellmeister's activity was stipulated by cultural demands of noblemen of the highest rank, which consisted in demand for universal specialist being able to carry out full control over a chapel as a music organization. That means that the authority of such individual among interested groups depended not on the level of skills possessed by the performing musician or exclusive giftedness of the pieces of music created by such person but on his/her universality - an ability to personally settle a wide range of issues, related not only to music. In particular, Romain Rolland considered that Jean-Baptiste Lully was successful only due to his fruitful diversified activity, and marked that the artist, when managing Paris Opera was an organizer, a conductor, a producer, an education specialist who also formed an orchestra and a choir ${ }^{28}$.

Since the end of the XVIIIth century, new historical conditions, related to bourgeois revolutions and formation of capitalist relations in

26 Новак Л. Йозеф Гайдн. Жизнь, творчество, историческое значение. Москва, 1973. С. 107, 358.

27 Ромен Роллан. Музыкально-историческое наследие. Вып. 1: История оперы в Европе до Люлли и Скарлатти. Истоки современного музыкального театра. Москва, 1986. С. 191-192.

${ }^{28}$ Ромен Роллан. Музыкально-историческое наследие. Вып. 3: Музыканты прошлых дней. Музыкальное путешествие в страну прошлого. Москва, 1988. C. 121 . 
Western Europe, led to professionalization in the music industry and, in particular, the differentiation within the kapellmeister's activity. It was primarily related to the formation of the composer's professionalism. The improvement and complication of the musical language against the background of ideological extension of the content made the composers demanding of the art quality of the performance within the context of upgrading the professional skills of music groups' performers. Those changes led to the appearance of professional musicians-education specialists, whose principal activity was the high-quality training of performing musician. At the same time, the aspiration for selfdevelopment led to the gradual concentration of musicians on specific kinds of professional activity, in particular, the musical piece and collective performance management.

Therefore, the formation of kapellmeister's activity was taking place within the limits of the Medieval church's culture, where the management of the music chapel was among the syncretical duties of clergymen. The differentiation of music activity in the European culture, which in the context of professionalization had been carrying out for centuries, stimulated gradual division of functions, inherent in sociocultural polyfunctional kapellmeister's activity, into separate kinds of professional activity and, in particular, the formation of the conductor's performance as an artistic form of carrying out control over the process of collective representation of the music text.

\section{The kapellmeister's activity and the aesthetics of performance}

System features of the kapellmeister's activity stipulated by its polyfunctionality: the kapellmeister's duties included organizational, pedagogical, the repertoire creator's, educational, performer's and conductor's functions $^{29}$. Such peculiarity made direct kapellmeister's effect on the aesthetics of performance of the music group under his control. To be appointed to the position of a music chapel master, a musician should have a corresponding professional image. The more authoritative was the chapel, the greater should be the musician's authority and experience. Christian Friedrich Daniel Schubart, mentioning that the genius was greatly manifested in the composition

29 Лошков Ю. Капельмейстерська діяльність та професійне музичне мистецтво європейської традиції // Традиції та новації у вищій архітектурнохудожній освіті. Харків, 2009. № 5. С. 29-32. 
and conducting a large orchestra, required from the kapellmeister, except for the ability to control the process of performance, solid theoretical knowledge and personal practice as a composer; the knowledge of "human hearts to be able to touch in masterly fashion its strings, like playing the favourite instrument ${ }^{30}$.

The artist was invited to provide the music organization functioning. The kapellmeister, following the purpose of the music group, performed an organizational function, in particular, was recruiting the performing musicians, was organizing the educational and rehearsal processes, in the course of which he was teaching music, implementing own methods and techniques, therefore, the professional quality of the music group depended on his effectiveness. For a long time, pedagogical skills were the mandatory requirement for the universal musician: the author of anonymous treatise of the XIIth century demanded from the musician to possess the skills to be able to teach others ${ }^{31}$, and at the end of XVIIIth century Joseph Haydn was training professionally the members of the Esterházy chapel. ${ }^{32}$.

Correcting the repertoire policy of a group, rehearsing, explaining the figurative content and peculiarities of performing the pieces of music, the kapellmeister was actively affecting the formation of its conception of the world and promoting its level of culture. The kapellmeisters representing different periods such as Gioseffo Zarlino, Johann Mattheson, Giuseppe Tartini, Johann Joseph Fux and others known as prominent music theorists, who undoubtedly were sharing their aesthetic opinions while communicating with the members of the groups headed by them.

For a long time, the ideological inspirers of aesthetic bases for collective music performance, and hence the kapellmeister's activity, were represented by clerics and aristocrats, whose peculiarities of moral education were stipulated by an aspiration for spiritual perfection. Focus on education of spiritual adviser for the congregation led to implementation in the Medieval period the fundamental education, which promoted conscious many-sided self-education of a person. Such

30 Музыкальная эстетика западноевропейского Средневековья и Возрождения. Москва, 1966. С. 337-338.

31 Музыкальная эстетика западноевропейского Средневековья и Возрождения. Москва, 1966. С. 53-54.

32 Новак Л. Йозеф Гайдн. Жизнь, творчество, историческое значение. Москва, 1973. С. 206. 
education, including the music, allowed to the clergymen to improve the divine servicing and, in particular, the background music. Later on, fundamental education became the prerogative of aristocratic circles. Following Antiquity and Medieval period, aristocracy as a form of government recognized the moral and educational significance of music: musicianship both in theory and in practice became a necessary element of secular education. Baldassare Castiglione an Italian writer in his treatise "The Book of the Courtier" (1518) wrote that a person cannot become a courtier if he is not a musician, does not play and knows nothing about the instruments ${ }^{33}$.

If in the medieval culture the spiritual authority belonged to the church, then in the secular culture the aristocratic circle became its "lawmaker" as an example for ambitious aspirations. Therefore, the solid education of a creator became the standard requirement for the creative work. Gioseffo Zarlino, an Italian theorist in his treatise "Le Dimostrationi Harmoniche" (1558) insisted on the fact that, except for the knowledge of music theory and practical skills (know how to play and tune the instrument), the composer should be knowledgeable in Geometry, Numeracy, Grammar, Dialectics, History, and Rhetoric ${ }^{34}$.

The attention paid to the management of collective performance as a professional kind of music (first of all due to its constant increasing effect on the level of orchestra music representation), is illustrated by the chain of papers published during the XIXth century. In particular, a book by F. Hasner "Dirigent und Ripienist" (1844) was the first attempt of comprehending the peculiarity of the process of control over the collective performance and distinguishing the professional features of the conductor - the performing musician. In the second half of the XIXth century, there were published the papers of the founders of aesthetics of the conductor's activity such as Hector Berlioz, Richard Wagner, Franz Liszt. The specific character of creative works of famous romanticmasters, who personified splendent talents of composers, performing musicians and thinkers, caused the aspiration for detecting a perfect, in their view, image of a conductor - the main mediator in bringing the author's message to the perfect hearer. Ideological basis for the aesthetics of performance in 1840 was formed in a work called On

\footnotetext{
33 Музыкальная эстетика западноевропейского и Возрождения. Москва, 1966. С. 75-76. 34 Музыкальная эстетика западноевропейского Средневековья и Возрождения. Москва, 1966. С. 78.

Средневековья
} 
German Music by Wilhelm Richard Wagner: "To be a conveyer of an artist's idea, a true representative of a creating composer - this role imposes on him special duties to keep art serious and clean in general: he, the performing musician, is a kind of a crossing point for an artistic thought, which, to some extent comes, true only through him...» ${ }^{35}$.

Alongside with this, the romantic thinkers were the first to bring up a problem of educating the listening public as the main task of the conductor's creative work. In the world of music for a long time, the relationships between the performing musician and the hearer were insignificant. At the early stage, the music-making was a part of the syncretic activity (religious, labour etc.), the content of which was clear even without background music. In the times of the European Medieval period, the hegemony of Christian church determined oration as the main theme of music. Praying of those present in the church united the priests - the leaders in the religious tradition and believers, blurring the spiritual boundaries between them. Thus, during the communal prayer, the congregation served as an active joint-performer, who understands the figurative sphere of music. Such syncretism was distinctive at the beginning of formation and joint instrumental performance, which was coming into the world in choir service within the XV-XVIth centuries.

From the moment of music formation as an educational art, and in particular its liberation from a religious cult, each music era was formed, was given figurativeness, and was herded by creative geniuses, it had given birth to. For a long time, it had been stipulated by the syncretic character of music activity, the peculiarity of which consisted in personifying the author of the artistic image and his representative. Johann Sebastian Bach and George Frideric Handel were popular as organists. François Couperin and Joseph Haydn were prominent harpsichordists etc. Thus, the prominent "universal" musicians, on the one hand, were forming the music performance style of the epoch, and on the other hand, were educating the listening public. And still, the music theorists of the XVIIIth century who were touching upon the subjects of the conductor's performance (J. Quantz, K. Juncker), paying much attention to the problem of interaction between the composer and the performing musician, actually omitted the phenomenon of a hearer. The attitude to the hearer, as to the "interlocutor", who understands the musical language at first glance, was inherent in that time composers. It

${ }^{35}$ Вагнер Р. Избранные работы. Москва, 1978. С. 71. 
was promoted by circumstances related to the cultivation of music in public life - high art was a prerogative of the elite both in the sphere of performance and in "consumption".

The evolution of "musical language" led the composers of the XIXth century to the attempts to reproduce through the music not the "outer" but the "inner". The flight of the composer's thought to ethicallymoral pinnacles had a tremendous bearing on the performance as well. The creative works of romanticists promoted the development of piano and strings performance, the formation of the contemporary conductor's activity. Essential is the fact that for some time the musician combined the author and performing musician all in one, continuing the traditions of the previous epochs. It is worth mentioning the names of Ludwig van Beethoven, Felix Mendelssohn, Franz Liszt (composers, conductors, pianists), Louis Spohr (a composer, a conductor, and the violin player) and others. Alongside with that, the formation of bourgeois relationships was promoted by the accumulation of listening public with the middleclass representatives, who were not knowledgeable in the sphere of music. Such circumstances, on the one hand, and complication of "the musical language", on the other hand, set a task of musical education before the progressive composers and performing musicians.

Thus, the prominent musicians of the XIXth century against the background of romantic aesthetics formulated in practice the principles of new artistic occupation - the conductor's performance, which were theoretically generalized in the works of Hector Berlioz, Richard Wagner, Franz Liszt. The educational principle became the basis for the aesthetics of the conductor's activity: the conductor is interpreting the music text following the author's conception, comprehended enough to be able to deliver it to the group of performing musicians, and then in the collective creative urge - to the public. In other words, the conductor, interpreting the piece of art, is engaged in self-education (personal comprehension), professional (practical reproduction of interpretation while working with a music group) and general aesthetic education (public performance of interpretation of the piece of music).

\section{The kapellmeister's activity and music text processing}

Constantly controlling the process of professional development of each performing musician and being aware of their technical capacities for some time the kapellmeister was performing the function of the repertoire creator. Regular actual practice with a music group optimized 
the process of the music text creation. The level of performance of the piece of music depended not only on the composer's skills of the creator but also on the intensity of composing music and the period of preparation for the public performance. Emphasizing the outstanding kapellmeister's abilities of Georg Reiter, who in the middle of the XVIIIth century was simultaneously heading the music groups of St. Stephen's Cathedral and the one at court of Charles VI in Vienna, Leopold Nowak mentioned that in a short period the musician had written many pieces, where "one could gradually start feeling a kind of lightness ${ }^{36}$. There is an interesting opinion expressed by Robert Schumann in this text, who in his review of the performance of a young composer said: "...Should I persuade him to write more? He is not rich enough and could become an artisan...» ${ }^{37}$. Therefore, the intensity of writing the "customized" pieces of music led to a casual, industrial attitude to the process of creation.

The industrial approach to the function of the repertoire creator was stipulated by the specific direction of music texts for the collective performance in the church or court environment, where following of deep-rooted traditions was the prerogative. This is the fact which is related to the following situation. When in exclusively individual creativity (painting, sculpture, etc.), also related to the church and court culture, much earlier there had been uncovered an individual element, the kapellmeister's music for a long time was within the limits of medieval aesthetics. However, like any system, the kapellmeister's activity allowed the personal fulfilment of people with outstanding abilities. Confirmation of this fact was the creative work of Joseph Haydn, who within the limits of kapellmeister's activity realized his potential as an ingenious composer, personally producing his pieces in the Esterházy chapel.

Just within the limits of the kapellmeister's activity the choral and orchestric performance evolved from freestyle composition to wellstructured and systematized kinds with specific forms of the music text reproduction. The peculiarity of the functional distribution of instrumental composition of "Baroque orchestra" was stipulated by the application of the composer's technique called "basso continuo" by the

36 Новак Л. Йозеф Гайдн. Жизнь, творчество, историческое значение. Москва, 1973. С. 107.

${ }^{37}$ Роберт Шуман. О музыке и музыкантах. Т. 2-А. Москва, 1978. С. 131. 
kapellmeisters until the end of the XVIIIth century, while performing the functions of the repertoire creator $^{38}$. The formation of the symphony orchestra as the functional system means for the music text reproduction was related to the creative work of the representatives of Viennese Classics, the most prominent of which were directly engaged in the kapellmeister's activity, and Joseph Haydn was one of them.

Immediately in the course of the performance, the kapellmeister was performing the function of the performing musician and a conductor. The application of different means of conducting was mainly caused not by the search for new forms of carrying out control over the collective performance, but an urgent practical necessity. It is known that JeanBaptiste Lully a prominent Italian when heading the Royal Academy of Music in Paris (1770-80s) was conducting an orchestra holding the violin in his hands ${ }^{39}$. Alongside with that, there is often recollected the fact causing the death of the artist (gangrene resulted from hitting the toe with battuta, which Lully used as a means of conducting the collective performance), which occurred during the performance of "Te Deum" in Feuillants the Paris church ${ }^{40}$. Wolfgang Amadeus Mozart during the concerts was conducting an orchestra with the violin, and at the premiere of the opera Don Juan in Prague, he was with the harpsichord. ${ }^{41}$.

At the same time, when Jean-Baptiste Lully was performing kapellmeister's activity in many cases the duty of performing musician and a conductor was performed by three assistants of the Italian: J.-F. Laluet, P. Collas and M. Mare ${ }^{42}$ [14, p. 121]. Robert Schumann mentioned that in the absence of Felix Mendelssohn - the kapellmeister of Leipzig Gewandhaus the orchestra was conducted by Ferdinand David

38 Лошков Ю. Засоби керівництва колективним виконавством в історії музичного мистецтва // Проблеми сучасності: культура, мистецтво, педагогіка: зб. наук. пр. Харків-Луганськ, 2005. С. 235-246.

39 Ливанова Т. История западноевропейской музыки до 1789 г. Т. 1 : От античности к XVIII веку. Москва, 1986. С. 253.

${ }^{40}$ Ромен Роллан. Музыкально-историческое наследие. Вып. 3: Музыканты прошлых дней. Музыкальное путешествие в страну прошлого. Москва, 1988. C. 105 .

41 Сидельников Л. Симфоническое исполнительство. Исторический очерк. Москва, 1991. С. 128.

42 Ромен Роллан. Музыкально-историческое наследие. Вып. 3: Музыканты прошлых дней. Музыкальное путешествие в страну прошлого. Москва, 1988. C. 121 . 
the leader of an orchestra ${ }^{43}$. Such practice was recorded in the references of the end of the XIXth century M. Solovyov stated that the leader of an orchestra - the first violinist, whose part contains the entrances of other instruments and singers, "in the event of oscillation in the orchestra during the performance should be the first to show the entrance by his play" and may even conduct the orchestra instead of kapellmeister ${ }^{44}$. Such situations occurred in the specific functioning of the military chapels in the XVII-XIXth centuries. The process of performance on the move (on the march) could be conducted by so-called "drum-major". The peculiarity of collective performance in this particular case consists in a loud and rhythmical play of marches, which does not require any special music talent from the one conducting the process, except for the maintenance of clear metro rhythm. Therefore, the drum-major was always a tall man, wearing a special uniform and holding a special twirling baton ${ }^{45}$. Thus, the evidence suggests that the kapellmeister could not perform the function of the performing musician and a conductor, in other words, the immediate control over the process of performance was not the main criterion for the professionalism of the chapel master.

It is necessary to mention the fact that a term for "conducting", as a control over the process of performance, was used by the artists in the XVIII-XIXth centuries not only within the context of orchestral performance. Joseph Haydn, describing his impressions of England, stated that while music-making "a trois" he was conducting the performance of his symphonies playing the piano ${ }^{46}$. Niccolò Paganini in the letter to his friend expressed the hope that the latter would like the last quartets of Ludwig van Beethoven when the violin player would conduct them ${ }^{47}$. In other words, the control over the process of musicmaking for a long time was understood not within the context of conducting the choral or orchestral performance but in an aesthetic sense of leadership in interpreting specific music text; the number of performing musicians was of no importance.

${ }^{43}$ Роберт Шуман. О музыке и музыкантах. Т. 2-А. Москва, 1978. С. 278.

44 Н. С. Концертмейстер // Ф. Брокгауз, И. Ефрон. Энцинклопедический словарь. Т. XVI. СПб., 1895. С. 360.

${ }^{45}$ Музыкальная энциклопедия. Т. 5. Москва, 1981. С. 406.

46 Новак Л. Йозеф Гайдн. Жизнь, творчество, историческое значение. Москва, 1973. С. 356.

47 Тибальди-Кьеза М. Паганини. Москва, 1981. С. 116. 
Alongside with this, the polyfunctionality of the kapellmeister's activity prevented from immediate dealing with creative issues: creating a certain performing interpretation. This process, as is commonly known, requires the concentration of all intellectual reserves of the brain, which in the ideal case is possible only due to special concentration, not overburden by the understanding of the necessity of performing other duties. On the other hand, the specific character of chapels' functioning, which consisted in a long-term stability of the composition, let the talented kapellmeisters achieve significant creative resultsB. Aleksey Pleshcheyev a Russian aristocrat and a musical amateur, after listening to the performance of serf orchestra in Oryol in 1816 was delighted with the performance: “...Great musicians! Such a rare thing in today's Europe! It is so natural! People, who are playing together since early childhood, must be much better -coordinated than those coming from the South and the North, gathered together in the evening, performing today, to anybody's liking.... ${ }^{48}$

Thus, within the limits of the kapellmeister's activity, there was formed an orchestra as the universal means, able to perform highly artistic tasks based on the representation of the music text recorded in the details. The evolution of the composer's creative work promoted the formation of a large creative repertoire, the quality of performance of which has become a criterion for excellence both the music group and its leader. This, in its turn, caused the negligence of the function of the repertoire creator and brought the performance function to the leading position, which stimulated the distinguishing of the conductor's activity as an equal kind of music performance.

\section{The kapellmeister's activity and music theory}

The universal musicians-kapellmeisters played an important part in the establishment of European scientific-theoretical thought in the sphere of music, in the development of the so-called Doctrine of the affections. In the XVIIth century René Descartes, the founder of Rationalism, a philosophical movement in his works "Compendium Musicus" (1618) and "Les passions de l'ậme" (1649) offered the notion of the goal of art, which is a stimulation and harmonization of physiologically stipulated

48 Глумов А., Доброхотов Б. Александр Плещеев // Музыкальное наследство. Сборники по истории музыкальной культуры СССР. Москва, 1976. C. $28-72$. 
affections, and the rational cognition of reasons initiating such excitation is made through philosophy and aesthetical theory ${ }^{49}$. Athanasius Kircher, a German mathematician, philologist, physicist and music theorist attempted to systematize affections, who in his book "Musurgia Universalis" (1650), based on three general passions: happiness, condonation and charity, developed the affections of joy, lust, anger, fear, hope, bravery, sympathy etc. ${ }^{50}$

In the next century, these ideas were approved by the kapellmeisters, who were applying the Doctrine of the affections in musical practice. In the XVIIIth century, the performance of not only own pieces of music (in a case of the orchestra- the pieces of music written by its leader) but also those created by other composers became a new standard of professional music-making. This process brought up before the musicians a problem of adequate reproduction of somebody else's intention in the course of performance. The abovementioned problem was one of the main factors for bringing attention to the Doctrine of the affections as a starting point for all the works of the time touching upon the issues related to the practice of music performance. The Doctrine of the affections formulated a new attitude to the tempo, destroying a specific length of notes inherent in the Medieval mensural notation, which necessitated the verbal marking that mainly referred to the nature of music. In the middle of the XVIIIth century, there was established a certain correlation between such marks and tempo ${ }^{51}$, in this regard the adepts of the Doctrine of the affections paid special attention to the problem of revealing the tempo as a decisive factor of successful performance of the piece of music. Therefore, the artists who were actively involved in the performance of music were trying to settle these issues in their theoretical works. Among them, there were the following prominent kapellmeisters of the time: Johann Mattheson (1681-1764), Friedrich Wilhelm Marpurg (17181795), Carl Philipp Emanuel Bach (1714-1788).

In 1739 there was published a work written by Johann Mattheson a German kapellmeister and musical theorist "Der vollkommene Cappellmeister", which summed up the process of author's comprehension of phenomenon called "an orchestra»: during the first

${ }^{49}$ Музыкальная эстетика Западной Европы XVII-XVIII веков. Москва, 1971. C. 341 .

${ }^{50}$ Музыкальная эстетика Западной Европы XVII-XVIII веков. Москва, 1971. C. 35 .

${ }^{51}$ Музыкальная энциклопедия. Т. 5. Москва, 1981. С. 491-493. 
quarter of the XVIIIth century there were published the works written by the above-mentioned author "Das neu-eröffnete Orchestre" (1713), "Das Beschütze Orchestre, oder desselben zweite Eröffnung" (1717), "Das forschende Orchestre" (1721). Johann Mattheson as an innovative composer considered the most difficult task for the one representing somebody else's piece of music the necessity to direct all mental capabilities to “...make sense of somebody else's thoughts. Those who do not know the way the author of the piece of music would personally perform it, are not likely to be able to do it well, otherwise, they will ruin its blood of life and beauty ...» ${ }^{52}$

In the second half of the XVIIIth century, there were published the famous works of German musicians Johann Joachim Quantz (16971773) "Versuch einer Anweisung die Flöte traversiere zu spielen" (1752) and Karl Ludwig Junker (1740-1797) - "Einige der vernehmsten Pflichten eines Kapellmeisters" (1782). The main principle for revealing the tempo by the conductor, according to K. Junker, was not "too poor" marks of the author, not the notion of down- or up-tempo itself, but only goal-orientation and an individual feeling - the only thing which necessitates the rate limiting of two opposite groups of affections Allegro or Adagio. German musicians were making practical suggestions on how to reveal the exact tempo. For example, J. Quantz uncovered and offered in practice the tempo distribution of the main affections based on human heart rate. To reveal the exact tempo K. Junker suggested exclusively practical way: to follow the nature of the instrument, in other words, its technical characteristics, and while singing - his vocal capacities $^{53}$.

The analysis of the works of musicians of the XVIIIth century, lets us make a conclusion regarding the absence at the time, at least on the theoretical level, the problem related to aesthetics of conducting the joint performance, nevertheless, each of the authors faced the collective performance in practice. It was stipulated by syncretism inherent in the sphere of the music of the time: the notion of "a musician" included almost everything related to the sphere of music - the writing of the piece of music and its performance, the educational process, the professional organization of the music group. This purpose, except for

52 Лайнсдорф Э. В защиту композитора: Альфа и омега искусства интерпретации. Москва,1988. С. 61.

Гинзбург Л. Дирижерское исполнительство: Практика. История. Эстетика. Москва, 1975. С. 38, 64. 
the talent, also required solid knowledge in the sphere of music. Thus, Johann Mattheson in his treatise called "Der vollkommene Cappellmeister" paid much attention to the following aspects: in the Introduction - to the necessity and benefits of music, the meaning of the melody; in the first section - to the nature of a sound, review of styles of music; in the second section - to the analysis of the rules on how to write the tunes; in the third section - to the problems of harmony, the rules of counterpoint, characteristics of some instruments ${ }^{54}$.

In such a way, the evolution of theoretical thought in the sphere of music worked its way from the application of the Doctrine of the affections by the thinkers of the XVIIth century to understand the music as a science industry, to processing of the Doctrine of the affections by professional kapellmeisters of the following century as a basis for further formation of the European music.

\section{CONCLUSIONS}

The conductor's performance as a kind of professional music activity, which is based on the representation of the author's text through the immediate control over the process of collective music-making, was formed within the limits of the kapellmeister's activity as a form sociocultural practice. The formation of the kapellmeister's activity as a gradual phenomenon in the history of music culture was stipulated by the process of professional differentiation and is characterized by polyfunctionality, which on the European music-making at the first evolutional stage was considered to be highest manifestation of talents: creation and management of the music group was the main criterion for practical application of the talent possessed by a musician, which caused an aspiration for kapellmeister's activity among the artists, choosing the music as their occupation.

The kapellmeister's activity as a kind of professional activity was functioning based on a specific system of standards, which had to be followed. In particular, during the performance of the function of the performing musician and a conductor, the standard included the means of carrying out control over the collective performance, which under certain conditions were clear to all the members participating in the process. At the same time, the informality of other standards - a composition of an

54 Музыкальная эстетика Западной Европы XVII-XVIII веков. Москва, 1971. C. 234 . 
orchestra, its location, a position of a conductor during the performance, aesthetic principles of reading the music text etc., caused the diversity of the applied means of carrying out control over the process. Only putting the above-mentioned standards in good order made the formation of a special mark system possible - the conductor manual technique as the professional language of communication among the members of the process of performance - a leader and a music group.

The formation of the music group, organized following the principle of comparison of groups, as a form and means of the music text reproduction, was taking place within the limits of kapellmeister's activity. The dynamics of the process of system formation of the music group was provided by comprehension of the music text by the kapellmeisters - the universal musicians. In this context, the conductor's activity evolved as a system of marks, focused on the best possible transmission of the information («the performer's model») for the reproduction of the text by the music group. Based on the kapellmeisters' professional experience, who realized in practice the philosophical comprehension of the music, there was formed a theoretical opinion as a form of creation, systematization, preservation and transmission of music texts. The final formation of system components of the kapellmeister's activity promoted the distinguishing of the conductor's performance as an art of a single manager of collective representation of the music text.

The necessity to study the kapellmeister's activity as a static and dynamic system phenomenon speeds up uncovering of the specificity for the formation of representative norms of the kapellmeister's activity on various stages of its formation, which will promote scientific comprehension of the kapellmeister's activity as a structural element of music culture.

\section{SUMMARY}

The subject of the study - the kapellmeister's activity as a systemic phenomenon. The methodological comprehension of the kapellmeister's activity as a system component of professional music activity was carried out by employing the system and activity approach. The goal of the research is to clear up the system features of kapellmeister's activity, which have been showing up in the course of the evolution of professional music. Clarification of the peculiar features of normative system functioning allows uncovering, on the one hand, the specific character of the kapellmeister's activity; on the other hand, the signs of kapellmeister's activity as a part of professional music. The 
kapellmeister's activity as a kind of professional activity was functioning based on a specific system of standards, which had to be followed. In particular, during the performance of the function of the performing musician and a conductor, the standard included the means of carrying out control over the collective performance. The informality of other standards - a composition of an orchestra, its location, a position of a conductor during the performance, aesthetic principles of reading the music text etc., caused the diversity of the applied means of carrying out control over the process. Only putting the above-mentioned standards in good order made the formation of a special mark system possible - the conductor manual technique as the professional language of communication among the members of the process of performance - a leader and a music group. The formation of the music group, organized following the principle of comparison of groups, as a form and means of the music text reproduction, was taking place within the limits of kapellmeister's activity. The dynamics of the process of system formation of the music group was provided by comprehension of the music text by the kapellmeisters - the universal musicians. In this context, the conductor's activity evolved as a system of marks, focused on the best possible transmission of the information («the performer's model») for the reproduction of the text by the music group. Based on the kapellmeisters' professional experience, who realized in practice the philosophical comprehension of the music, there was formed a theoretical opinion as a form of creation, systematization, preservation and transmission of music texts. The final formation of system components of the kapellmeister's activity promoted the distinguishing of the conductor's performance as an art of a single manager of collective representation of the music text.

\section{REFERENCES}

1. Багриновский М. Дирижерская техника рук. М. : ВУВД СА, 1947. $290 \mathrm{c}$.

2. Вагнер Р. Избранные работы. М. : Музыка, 1978. 695 с.

3. Гинзбург Л. Дирижерское исполнительство: Практика. История. Эстетика. М. : Музыка, 1975. 629 с.

4. Глинский М. Очерки по истории дирижерского искусства // Музыкальный современник. 1916. № 3. С. 26-62.

5. Глумов А., Доброхотов Б. Александр Плещеев // Музыкальное наследство: сборники по истории музыкальной культуры СССР. Т. 4. М. : Гос. муз. изд-во, 1976. С. 28-72. 
6. Головинский Г. Композитор и фольклор: Из опыта мастеров XIX - XX веков. Очерки. М. : Музыка, 1981. 279 с. $485 \mathrm{c}$.

7. Грубер Р. Всеобщая история музыки. М. : Музыка, 1965.

8. Лайнсдорф Э. В защиту композитора: Альфа и омега искусства интерпретации. М. : Музыка, 1988. 303 с.

9. Ливанова Т. История западноевропейской музыки до 1789 г. T. 1 : От античности к XVIII веку. М. : Музыка, 1986. 462 с.

10. Ливанова Т. История западноевропейской музыки до 1789 г. T. 2: XVIII век. М. : Музыка, 1982. 622 с.

11. Лошков Ю. Засоби керівництва колективним виконавством в історії музичного мистецтва // Проблеми сучасності: культура, мистецтво, педагогіка: зб. наук. пр. Харків-Луганськ : “Стилыздат”, 2005. C. 235-246.

12. Лошков Ю. Капельмейстерська діяльність та професійне музичне мистецтво європейської традиції // Традиції та новації у вищій архітектурно-художній освіті : зб. наук. пр. Харків : ХДАДМ, 2009. № 5. C. 29-32.

13. Лошков Ю. Профессиональное музыкальное искусство европейского типа // Мистецтвознавство XX століття. Херсон, 2017. C. $13-48$.

14. Макаренко Г. Творчість диригента: Естетикомистецтвознавчі виміри. Київ: “Факт”, 2005. 328 с.

15. Материалы и документы по истории музыки. Т. II: XVIII век (Италия, Франция, Германия, Англия). М. : ОГИЗ - Гос. муз. изд-во, 1934. 603 c.

16. Музыкальная энциклопедия. Т. 2. М. : Сов. энциклопедия, 1974.960 c.

17. Музыкальная энциклопедия. Т. 5. М. : Сов. энциклопедия, 1981. $1056 \mathrm{c}$.

18. Музыкальная эстетика западноевропейского Средневековья и Возрождения. М. : Музыка, 1966. 574 с.

19. Музыкальная эстетика Западной Европы XVII-XVIII веков. М. : Музыка, 1971. 688 с.

20. Н. С. Капельмейстер // Ф. Брокгауз, И. Ефрон. Энциклопедический словарь. T. XIV. СПб. : Типо-Литография И. А. Ефрона, 1895. С. 146.

21. Н. С. Концертмейстер // Ф. Брокгауз, И. Ефрон. Энцинклопедический словарь. T. XVI. СПб. :Типо-Литография И. А. Ефрона, 1895. С. 360. 
22. Назайкинский Е. О психологии музыкального восприятия. М. : Музыка, 1972. 383 с.

23. Новак Л. Йозеф Гайдн. Жизнь, творчество, историческое значение. М. : Музыка, 1973. 448 с.

24. Плужников B. Профессия дирижера и пути еe формирования в западноевропейской театрально-концертной практике XIX века : дисс. ... канд. искусствоведения : 17.00.03. Харьков, 2006. 237 с.

25. Роберт Шуман. О музыке и музыкантах. Т. 2-А. М. : Музыка, 1978. 327 с.

26. Ромен Роллан. Музыкально-историческое наследие. Вып. 1: История оперы в Европе до Люлли и Скарлатти. Истоки современного музыкального театра. М. : Музыка, 1986. 311 с.

27. Ромен Роллан. Музыкально-историческое наследие. Вып. 3: Музыканты прошлых дней. Музыкальное путешествие в страну прошлого. М. : Музыка, 1988. 448 с.

28. Сидельников Л. Симфоническое исполнительство. Исторический очерк. М. : Сов. композитор, 1991. 286 с.

29. Тибальди-Кьеза М. Паганини. М. : Молодая гвардия, 1981. $303 \mathrm{c}$.

30. Щедровицкий Г. П. Избранные труды. М. : Шк. Культ. Полит., 1995.800 с.

31. Энгель Ю. Краткий музыкальный словарь. М. : Изд-во П. Юргенсона, 1907. 216 с.

Information about the author: Loshkov Yu. I., Doctor of Fine Arts, Professor at the Department of Folk Instruments, Vice-Rector, Kharkiv State Academy of Culture 4, Bursatski Uzviz, Kharkiv, 61057, Ukraine 